disease $20(35 \%)$ pts, esophageal involvement $29(51 \%)$ pts of them $5(9 \%)$ pts needed enteral feeding. 2 (4\%) pts had oncopathology. CK was increased in 49 (86\%) pts: < $10 \mathrm{~N}-15$ (26\%) pts, >10 N - 28 (49\%) pts, > $50 \mathrm{~N}-6(11 \%)$. ANA positive - in 39 (70\%) pts. Antibodies identified in 25(44\%) pts: Pm-Scl 7 (12\%) pts, PL-7 1 (2\%), Mi-2 10 (17,5\%), Ku 2 (3,5\%) pts, AMA-M2 2 (2\%)pts, a-SRP 4 (7\%) and SS-A/Ro-52 13 (23\%), SS-A/Ro-60 2 (3\%) pts.

Conclusion: The group of inflammatory myopathies is characterized by clinical and immunological heterogeneity. Finding antibodies specific for myositis can help diagnose the disease.

Disclosure of Interests: None declared.

DOI: 10.1136/annrheumdis-2021-eular.3101

\section{AB0445 $\quad$ FIRST CLINICAL ANALYSIS OF MYOSITIS PATIENTS REGISTERED AT REUMA.PT/MYOSITIS PROTOCOL: DATA FROM A SINGLE-CENTER}

A. T. Melo ${ }^{1,2}$, E. Dourado ${ }^{1,2}$, P. Martins ${ }^{1,2}$, N. Khmelinskii ${ }^{1,2}$, J. E. Fonseca ${ }^{1,2}$ I. Cordeiro ${ }^{1,2}$, R. Campanilho-Marques ${ }^{1,2}$. $^{1}$ Lisbon, Serviço de Reumatologia e Doenças Ósseas Metabólicas, Hospital de Santa Maria, CHULN, Centro Hospitalar Universitário Lisboa Norte, Lisbon, Portugal; ${ }^{2}$ Lisbon, Unidade de Investigação em Reumatologia, Instituto de Medicina Molecular, Faculdade de Medicina, Universidade de Lisboa, Centro Académico de Medicina de Lisboa, Lisbon, Portugal

Background: Idiopathic inflammatory myopathies are a group of rare heterogeneous diseases that require a multidisciplinary and standardized approach.

Table 1. Clinical characteristics and immunological profile of the patients.

\begin{tabular}{|c|c|c|c|c|c|c|}
\hline \multirow[t]{2}{*}{ Diagnosis (n) } & \multicolumn{5}{|c|}{ Clinical features } & \multirow[t]{2}{*}{ Myositis antibodies (n) } \\
\hline & $\begin{array}{l}\text { Skin } \\
\text { disease, } \\
\text { median } \\
{[I Q R] /(n)}\end{array}$ & $\begin{array}{c}\text { MMT-8, } \\
\text { median } \\
\text { [IQR] }\end{array}$ & $\begin{array}{l}\text { Lung } \\
\text { disease } \\
\text { (n) }\end{array}$ & $\begin{array}{l}\text { Others } \\
(n)\end{array}$ & $\begin{array}{l}\text { Malignancy } \\
\text { (n) }\end{array}$ & \\
\hline $\begin{array}{l}\text { Definite DM } \\
\quad(28)\end{array}$ & $\begin{array}{l}\text { DAS Skin } \\
2 \text { [0-2] } \\
\text { Calcinosis } \\
\text { (3) } \\
\text { Mechanic } \\
\text { hands (2) }\end{array}$ & $\begin{array}{c}80 \\
{[75-80]}\end{array}$ & $\begin{array}{c}\text { NSIP } \\
(2) ; \\
\operatorname{COP}(1)\end{array}$ & $\begin{array}{l}\text { Arthritis } \\
\text { (6) }\end{array}$ & $\begin{array}{l}\text { Breast } \\
\text { cancer } \\
(1)\end{array}$ & $\begin{array}{l}\text { anti-Ro52 (6); anti-Mi2b } \\
\text { (5); anti-PmScl100 (4); } \\
\text { anti-MI2a (3); anti-NXP2 } \\
\text { (3); anti-SAE (2); anti- } \\
\text { MDA5 (2); anti-Ku (2); } \\
\text { anti-Tif1g (1) }\end{array}$ \\
\hline $\begin{array}{l}\text { Antisynthetase } \\
\text { syndrome } \\
\text { (21) }\end{array}$ & $\begin{array}{l}\text { DAS Skin } \\
0[0-0] \\
\text { Calcinosis } \\
(1) \\
\text { Mechanic } \\
\text { hands (4) }\end{array}$ & $\begin{array}{c}80 \\
{[80-80]}\end{array}$ & $\begin{array}{l}\text { NSIP } \\
(11) ; \\
\text { UIP (3); } \\
\operatorname{LIP}(1)\end{array}$ & $\begin{array}{l}\text { Arthritis } \\
\text { (15); } \\
\operatorname{RP}(10)\end{array}$ & - & $\begin{array}{c}\text { anti-Jo1 (14); } \\
\text { anti-Ro52 (12); } \\
\text { anti-Mi2b (1); } \\
\text { anti-PL7 (3); } \\
\text { anti-PL12 (1) }\end{array}$ \\
\hline $\begin{array}{l}\text { Probable DM } \\
\text { (19) }\end{array}$ & $\begin{array}{l}\text { DAS Skin } \\
0[0-0]\end{array}$ & $\begin{array}{c}80 \\
{[78-80]}\end{array}$ & COP (1) & $\begin{array}{l}\text { Arthritis } \\
(5) ; \\
\operatorname{RP}(6)\end{array}$ & - & $\begin{array}{c}\text { anti-Mi2a (4); } \\
\text { anti-Mi2b (2); anti-Tif1g (2); } \\
\text { anti-Ku (2); } \\
\text { anti-PmScl75 (2) }\end{array}$ \\
\hline CADM (16) & $\begin{array}{l}\text { DAS Skin } \\
1 \text { [0-2] } \\
\text { Calcinosis } \\
(1) \\
\text { Mechanic } \\
\text { hands (1) }\end{array}$ & $\begin{array}{c}80 \\
{[77-80]}\end{array}$ & $\begin{array}{l}\text { NSIP } \\
(1) ; \\
\text { COP } \\
(1)\end{array}$ & $\begin{array}{l}\text { Arthritis } \\
\text { (5); } \\
\operatorname{RP}(4)\end{array}$ & - & $\begin{array}{c}\text { anti-Mi2b (5); } \\
\text { anti-Ro52 (2); anti-Mi2a (1); } \\
\text { anti-MDA5 (1); anti-EJ (1); } \\
\text { anti-SAE (1); anti-SRP (1); } \\
\text { anti-Ku (1); anti-Tif1g (1) }\end{array}$ \\
\hline MCTD (12) & $\begin{array}{l}\text { DAS Skin } \\
0[0-1]\end{array}$ & $\begin{array}{c}80 \\
{[79-80]}\end{array}$ & $\begin{array}{l}\text { NSIP } \\
(1)\end{array}$ & $\begin{array}{l}\text { Arthritis } \\
\quad(8) ; \\
\operatorname{RP}(10)\end{array}$ & - & $\begin{array}{l}\text { anti-U1 RNP (12); } \\
\text { anti-Ro52 (7) }\end{array}$ \\
\hline PM (7) & $\begin{array}{l}\text { DAS Skin } \\
0[0-0] \\
\text { Calcinosis } \\
(1)\end{array}$ & $\begin{array}{c}80 \\
{[72-80]}\end{array}$ & $\begin{array}{l}\text { NSIP } \\
(1)\end{array}$ & $\begin{array}{l}\text { Arthritis } \\
\text { (1) }\end{array}$ & $\begin{array}{l}\text { Ovarian cancer } \\
\text { (1); non-Hodg- } \\
\text { kin lymphoma } \\
\text { (1) }\end{array}$ & $\begin{array}{c}\text { anti-Ro52 (2); } \\
\text { anti-SRP (1) }\end{array}$ \\
\hline UCTD (5) & $\begin{array}{l}\text { DAS Skin } \\
0[0-2] \\
\text { Calcinosis } \\
\quad(1) \\
\text { Mechanic } \\
\text { hands (1) }\end{array}$ & $\begin{array}{c}80 \\
{[79-80]}\end{array}$ & $\begin{array}{l}\text { NSIP } \\
(2)\end{array}$ & $\begin{array}{l}\text { Arthritis } \\
\quad(1) ; \\
\operatorname{RP}(5)\end{array}$ & - & $\begin{array}{l}\text { anti-ThTo (2); } \\
\text { anti-SRP (1); } \\
\text { anti-PL12 (1) }\end{array}$ \\
\hline $\begin{array}{l}\text { Overlap syn- } \\
\text { dromes (12) }\end{array}$ & $\begin{array}{l}\text { DAS Skin } \\
0 \text { [0-2] } \\
\text { Mechanic } \\
\text { hands (2) }\end{array}$ & $\begin{array}{c}80 \\
{[77-80]}\end{array}$ & $\begin{array}{l}\text { NSIP } \\
(3) ; \\
\text { UIP (1) }\end{array}$ & $\begin{array}{l}\text { Arthritis } \\
\text { (4); } \\
\operatorname{RP}(8)\end{array}$ & - & $\begin{array}{l}\text { anti-PmScl75 (4); anti-Pm- } \\
\text { Scl100 (1); anti-Ro52 (1); } \\
\text { anti-Ro60 (1); anti-RNAPIII } \\
\text { (1); anti-NOR90 (1); } \\
\text { anti-MDA5 (1); anti-Ku (1) }\end{array}$ \\
\hline $\begin{array}{l}\text { Necrotizing } \\
\text { myopathy (1) }\end{array}$ & $\begin{array}{l}\text { DAS } \\
\text { Skin } 0\end{array}$ & 80 & - & - & - & - \\
\hline
\end{tabular}

DM - dermatomyositis; CADM - clinically amyopathic dermatomyositis; MCTD - mixed connective tissue disease; PM - polymyositis; UCTD - undifferentiated connective tissue disease ILD - interstitial lung disease; NSIP - nonspecific interstitial pneumonia; LIP - lymphocytic interstitial pneumonitis; UIP - usual interstitial pneumonia; COP - cryptogenic organizing pneumonia; RP - Raynaud phenomenon
Objectives: To clinically characterize patients with inflammatory myopathies followed at an hospital's Rheumatology Department, using the Rheumatic Diseases Portuguese Register (Reuma.pt)

Methods: An observational transversal study was performed. Data on demographic variables, clinical features, antibodies and treatment were collected. Results: Of the 121 included patients, $78 \%$ were female, with a median age of 56 [44-68] years and a median disease duration of 2 [0-4] years. The mos frequent diagnosis was dermatomyositis ( $D M ; n=28,23 \%)$ followed by antisynthetase syndrome (ASyS; $n=21,17.4 \%$ ). At the time of the analysis, the median Manual Muscle Test (MMT-8) was 80 [78-80], the median modified skin Disease Activity Score was 0 [0-2] and global disease activity was 0.5 [0-0.75]. Calcinosis was found in $6 \%$ of the patients $(n=7)$, mostly DM cases. Interstitial lung disease (ILD) was present in 29 patients (24\%), of those, $52 \%(n=15)$ had antisynthetase syndrome (ASyS). Three patients presented as a paraneoplastic syndrome. Ninety-nine patients $(82 \%)$ had a myositis autoantibody identified: antisynthetase autoantibodies were the most commonly identified $(n=20,16 \%)$ $62 \%$ of the patients were treated with steroids and $35 \%$ with $\geq 2$ disease-modifying anti-rheumatic drugs.

Table 1 depicts the main clinical characteristics and the immunologic profile for each diagnosis

Conclusion: In our cohort the most frequent myositis subtype was DM. Almost a quarter of patients had associated ILD, which is an important cause of morbidity and mortality. ILD was more frequent in ASyS patients and was most commonly related to anti-Jo1 antibodies, which is consistent with the literature.

Disclosure of Interests: None declared.

DOI: 10.1136/annrheumdis-2021-eular.3150

AB0446
DEMOGRAPHIC AND CLINICAL FEATURES OF
IDIOPATHIC INFLAMMATORY MYOSITIS AND
PREVALENCE OF MYOSITIS-RELATED ANTIBODIES

G. K. Yardımcı ${ }^{1}$, E. Erul ${ }^{2}$, B. Farisoğulları ${ }^{1}$, G. Ayan ${ }^{1}$, L. Kılıç ${ }^{1}$, O. Karadag ${ }^{1}$, Ş. A. Bilgen '. ${ }^{1}$ Faculty of Medicine; Hacettepe University, Rheumatology, Ankara, Turkey; ${ }^{2}$ Faculty of Medicine; Hacettepe University, Internal Medicine, Ankara, Turkey

Background: Idiopathic inflammatory myopathies (IIM) are heterogeneous groups of connective tissue diseases. Diagnosis of IIM is sometimes challenging, but newly defined myositis specific autoantibodies (MSAs) are helpful in diagnosing of IIM and revealing the clinical signs [1].

Objectives: To describe demographic and clinical features of IIMs and to evaluate the frequency and clinical associations of myositis-specific and myositis associated antibodies (MAAs) in IIM.

Methods: Samples obtained from patients tested for MSA/MAA as of 2017 to 2020 were retrospectively evaluated. Patients were diagnosed with IIM according to clinician diagnosis. The prevalence and clinical associations of myositis-related antibodies were assessed with univariate and multivariate analysis.

Results: 152 patients (70.4\% female) were tested for myositis-related antibodies during the study period. 81 patients were diagnosed with IIM (38 DM, 43PM). DM patients were diagnosed at an earlier age and its association with malignancy was more relevant, although the relationship with malignancy was not statistically significant. Differences of clinical characteristics between DM and PM patients were skin features which were more frequent in DM, and interstitial lung disease which was more common in PM patients.

MSAs/MAAS were found in $65.4 \%$ and $43.2 \%$ in IIM patients, more frequently than patients without IIM ( $p=0.000$ and 0.0225 , respectively). MSAs were equally frequent in both IIM groups, whereas MAAs were more common in the PM group (although no significant difference in overlap with other connective tissue diseases within these two diseases). The most common MSAs in DM were antiTIF1- $\gamma(23 \%)$, anti-MDA5 (16\%), anti-NXP2 (13\%) and in PM were anti-Jo-1 (28\%), anti-MDA5 (12\%), anti-ku (12\%), anti-PL7 (12\%) respectively. Predictors of ILD in IIM were Anti-Jo-1 positivity and age (RR:10 [Cl:2-41] p=0.003 and RR:1.07 [Cl:1.02-1.12] $\mathrm{p}=0.04$ respectively)

Conclusion: The general characteristics of DM and PM patients and the frequencies of myositis-specific autoantibodies were similar to the literature, except that anti-TIF1- $\gamma$ antibodies (14\%) were more common in our Turkish cohort [2].

\section{REFERENCES:}

[1] Cruellas, M.G., et al., Myositis-specific and myositis-associated autoantibody profiles and their clinical associations in a large series of patients with polymyositis and dermatomyositis. Clinics (Sao Paulo), 2013. 68(7): p. 909-14.

[2] Gonzalez-Bello, Y., et al., Myositis-Specific Antibodies and Myositis-Associated Antibodies in Patients With Idiopathic Inflammatory Myopathies From the PANLAR Myositis Study Group. J Clin Rheumatol, 2020. 